\title{
In vitro human cell-based TTR-TR $\beta$ CALUX assay indicates thyroid hormone transport disruption of short-chain, medium-chain, and long-chain chlorinated paraffins
}

\author{
Jannik Sprengel ${ }^{1}$ (D) Peter A. Behnisch ${ }^{2} \cdot$ Harrie Besselink $^{2} \cdot$ Abraham Brouwer $^{2} \cdot$ Walter Vetter $^{1}$ (D)
}

Received: 2 November 2020 / Accepted: 28 January 2021 / Published online: 8 February 2021

(c) The Author(s) 2021

\begin{abstract}
Over the last decades, short-chain chlorinated paraffins (SCCPs), medium-chain chlorinated paraffins (MCCPs), and longchain chlorinated paraffins (LCCPs) have become the most heavily produced monomeric organohalogen compound class of environmental concern. However, knowledge about their toxicology is still scarce, although SCCPs were shown to have effects on the thyroid hormone system. The lack of data in the case of MCCPs and LCCPs and the structural similarity with perfluoroalkyl substances (PFAS) prompted us to test CPs in the novel TTR-TR CALUX assay for their thyroid hormone transport disrupting potential. Four self-synthesized and additionally purified single chain length $\mathrm{CP}$ mixtures $\left(\mathrm{C}_{10}-\mathrm{CPs}\right.$, $\mathrm{C}_{11}$-CPs, $\mathrm{C}_{14}$-CPs and $\mathrm{C}_{16}$-CPs) and two each of industrial MCCP and LCCP products were tested in parallel with PFOA. All CP mixtures influenced the TTR binding of T4, giving activities of 1,300 to 17,000 $\mu \mathrm{g} / \mathrm{g}$ PFOA equivalents and lowest observable effect concentrations (LOELs) of 0.95 to $0.029 \mathrm{mM} / \mathrm{L}$ incubate. Highest activities and lowest LOELs were observed for $\mathrm{C}_{16}$-CPs (48.3\% Cl content, activity 17,000, LOEL $\left.0.047 \mathrm{mM} / \mathrm{L}\right)$ and a LCCP mixture $(71.7 \% \mathrm{Cl}$ content; activity 10,000; LOEL $0.029 \mathrm{mM} / \mathrm{L}$ ). A trend of higher activities and lower LOELs towards longer chains and higher chlorination degrees was implied, but could not be statistically confirmed. Irrespectively, the less well examined and current-use LCCPs showed the highest response in the TTR-TR $\beta$ CALUX assay.
\end{abstract}

Keywords Polychlorinated $n$-alkane $\cdot$ Chloroparaffin $\cdot$ Thyroid disruption · Countercurrent chromatography $\cdot$ Thyroxine Bioassay · TTR-TR $\beta$ CALUX

\section{Introduction}

Chlorinated paraffins (CPs) are a group of current-use anthropogenic organohalogenated chemicals ubiquitously detected in the environment (Glüge et al. 2016, 2018; van Mourik et al. 2016). CPs are industrially produced by the chlorination of mixtures of alkane stocks to a desired degree of chlorination of typically 42, 52, or $70 \mathrm{wt} \%$ (Sprengel and Vetter 2019; Glüge et al. 2018). Irrespective of chain length range and chlorination degree, each of the resulting technical CP mixtures consists of thousands of homologues whose

Walter Vetter

walter.vetter@uni-hohenheim.de

1 Institute of Food Chemistry (170B), University of Hohenheim, Garbenstr. 28, 70599 Stuttgart, Germany

2 BioDetection Systems B.V. (BDS), Science Park 406, 1098 XH Amsterdam, Netherlands individual structures are widely unknown. According to the ranges of alkane chains, they are subdivided into short-chain CPs (SCCPs, $\mathrm{C}_{10-13}$ ), medium-chain CPs (MCCPs, $\mathrm{C}_{14-17}$ ) and long-chain CPs (LCCPs, $>\mathrm{C}_{17}$ ). SCCPs were shown to be persistent, bioaccumulative and toxic, and thus considered as environmentally harmful compounds. Consequently, SCCPs were added to Annex A of the Stockholm Convention in 2017 (Conference of the Parties to the Stockholm Convention 2017). Given the structural similarity of SCCPs with MCCPs and LCCPs_-which are only differing by chain lengths - similar detrimental environmental properties could be shown by the presence of (mainly) MCCPs in a wide range of samples (He et al. 2019; Wu et al. 2019; Hilger et al. 2013; Wang et al. 2019; Li et al. 2017). Arguably, this similarity in structure and environmental properties could also be valid in the case of toxicity. However, toxicological data on MCCPs and especially LCCPs are scarcely found in the scientific literature. For instance, SCCPs were shown to reduce levels of the thyroid hormones triiodothyroxine 
(T3) and thyroxine (T4) (Gong et al. 2018), causing developmental defects in zebrafish (Liu et al. 2016) and cancer in mice and rats (Wyatt et al. 1993). Compared to that only one technical MCCP product $(40 \% \mathrm{Cl})$ was shown to interfere with thyroid hormones similar to SCCPs (Wyatt et al. 1993), and no data existed on the thyroid disruptive potential of LCCPs. Recently, poly- and perfluoroalkyl substances (PFAS) like perfluorooctanoic acid (PFOA) were shown to competitively bind to the thyroid transport protein transthyretin (TTR), which can lead to reduced thyroid hormone levels (Weiss et al. 2009). Moreover, a fast and reproducible cell line-based CALUX bioassay was introduced which enabled monitoring of thyroid hormone transport disruption by combining a TTR-binding assay with a TR $\beta$ CALUX detection assay (TTR-TR $\beta$ CALUX) (Collet et al. 2019). The strong dose-dependent TTR-binding potency of PFOA could be confirmed in this bioassay (Collet et al. 2019). Given the structural similarity with PFOA (both consisting of long, unbranched carbon chains with a high level of halogenation), we reasoned that CPs may also give response in the TTR-TR $\beta$ CALUX bioassay and that this test could be used to monitor thyroidal responses induced by CPs.

Hence, the goal of this study was to assess the thyroid disruptive potential of CP products by means of the TTR-TR $\beta$ CALUX bioassay initially developed for polyhalogenated compounds. For this purpose, four technical CP products and four self-synthesized single chain length CP mixtures were used as substrates (Sprengel et al. 2019). Due to the possible presence of impurities in these products (Heeb et al. 2020), all single chain length CP mixtures were initially purified from potential impurities by means of countercurrent chromatography (CCC). CCC is a preparative all-liquid based instrumental method (Ito 2005) that is widely used for the isolation of natural products (Friesen et al. 2015). However, its merits were also shown in the fractionation of mixtures of polyhalogenated compounds (Gallistl and Vetter 2016; Kapp and Vetter 2009; Vetter et al. 2012). Dose ranges of CP products and mixtures were incubated with TTR and $\mathrm{T} 4$ for binding competition. Thereafter the remaining $\mathrm{T} 4$ bound to TTR was analyzed using the TR $\beta$ reporter assay. All CP products showed thyroid hormone disruptive potential in the TTR-TR $\beta$ CALUX bioassay.

\section{Materials and methods}

\section{Industrial CP products and single chain length CP mixtures}

The four industrial $\mathrm{CP}$ products were produced in China. Two consisted almost exclusively of MCCPs and the remaining two of LCCPs. Following their recent characterization by gas chromatography with electron capture negative ion mass spectrometry (GC/ECNI-MS) and nuclear magnetic resonance spectroscopy (NMR) (Sprengel and Vetter 2020), these were labeled A-52 (MCCP-1), B-52 (MCCP-2), A-42 (LCCP-1) and A-70 (LCCP-2) with the initial letter indicating two producers ( $\mathrm{A}$ and $\mathrm{B}$ ) and the number representing the approximate degree of chlorination in weight\% (namely $42 \%, 52 \%$ or $70 \%$ ) (Sprengel and Vetter 2020). Four selfsynthesized single chain length $\mathrm{CP}$ mixtures were tested as well. Namely, a $\mathrm{C}_{10}$-CP mixture with $49.3 \% \mathrm{Cl}$ content and a $\mathrm{C}_{11}$-CP mixture with $49.8 \% \mathrm{Cl}$ content were selected as representatives for SCCPs and a $\mathrm{C}_{14}$-CP mixture with $50.1 \% \mathrm{Cl}$ content and a $\mathrm{C}_{16}$-CP with $48.3 \%$ content $\mathrm{Cl}$ were chosen to represent the MCCP range (Sprengel et al. 2019). Recently, it was found that the synthesis route of Sprengel et al. (2019) might contain sulfur-containing impurities (Heeb et al. 2020). To exclude that these could affect the measurements, the four single chain $\mathrm{CP}$ mixtures were further purified by CCC before they were applied to the TTRTR $\beta$ CALUX bioassay (section Clean-up of self-synthesized CPs via countercurrent chromatography (CCC)). Of all CP samples $\sim 12 \mathrm{mg}$ were used for the assay.

\section{Clean-up of self-synthesized CPs via countercurrent chromatography (CCC)}

CCC fractionation of single chain $\mathrm{CP}$ mixtures was performed with an AECS QuikPrep MK8 instrument (London, U.K.) using the standard setup and the BTF solvent system ( $n$-hexane/acetonitrile/ $\alpha, \alpha, \alpha$-trifluorotoluene (20:13:7, v:v:v)) of Englert et al. (Englert et al. 2015). Coil 1 (123 mL) was used for the separation. After filling the coil with stationary phase, rotation was set to the maximum value of $870 \mathrm{rpm}$ and mobile phase was pumped into the system at $10 \mathrm{~mL} / \mathrm{min}$ until its breakthrough and stabilization of the system (retention of the stationary phase: $\mathrm{S}_{\mathrm{f}}=75 \%$ ). Then, the flow rate was decreased to $3.5 \mathrm{~mL} / \mathrm{min}$ and $\sim 500 \mathrm{mg}$ of the respective $\mathrm{CP}$ product, dissolved in $10 \mathrm{~mL}$ upper phase, was injected into the CCC system. The first $130 \mathrm{~mL}$ $\left(\mathrm{C}_{10}\right.$-CPs $), 150 \mathrm{~mL}\left(\mathrm{C}_{11}\right.$-CPs $), 180 \mathrm{~mL}\left(\mathrm{C}_{14}\right.$-CPs $)$ or $190 \mathrm{~mL}$ $\left(\mathrm{C}_{16}\right.$-CPs) were collected as one fraction containing the more polar sulfur-containing impurities. After that, 10 fractions of $7 \mathrm{~mL}$ each were collected, respectively. Then, the coil was purged with methanol at $10 \mathrm{~mL} / \mathrm{min}$ for displacement of the stationary phase which was also collected. Individual $\mathrm{CCC}$ fractions were evaporated to dryness, weighed and re-dissolved with iso-octane (for pesticide residue analysis grade) to give concentrations of $\sim 200 \mathrm{ng} / \mu \mathrm{L}$. These solutions were analyzed by GC/ECNI-MS analysis to check for purity of the fraction. Sulfur-containing impurities were monitored by $\mathrm{GC} / \mathrm{ECNI}-\mathrm{MS}$ operated in full scan mode by extraction of $\mathrm{m} / z 99$ and $101\left(\left[\mathrm{SO}_{2} \mathrm{Cl}\right]^{-}\right)$from the total ion current which were additionally requested to be present in the ratio 2.68:1. 
Table 1 Impurity-free CPs gained from CCC clean-up of self-synthesized single chain length CP standards

\begin{tabular}{lllll}
\hline CP standard & $\begin{array}{l}\text { Chlorination degree of } \\
\text { raw product }(\%)\end{array}$ & $\begin{array}{l}\text { Amount of raw } \\
\text { product }(\mathrm{mg})\end{array}$ & $\begin{array}{l}\text { Start of pure CP } \\
\text { fraction }(\mathrm{mL})\end{array}$ & $\begin{array}{l}\text { Amount of pure } \\
\text { CP fraction }(\mathrm{mg})\end{array}$ \\
\hline $\mathrm{C}_{10}-\mathrm{CP}(49.3 . \% \mathrm{Cl})$ & 50.3 & 487 & 151 & 173 \\
$\mathrm{C}_{11}-\mathrm{CP}(49.8 \% \mathrm{Cl})$ & 51.2 & 494 & 164 & 333 \\
$\mathrm{C}_{14}-\mathrm{CP}(50.1 \% \mathrm{Cl})$ & 51.8 & 640 & 187 & 177 \\
$\mathrm{C}_{16}-\mathrm{CP}(48.3 \% \mathrm{Cl})$ & 50.9 & 269 & 218 & 234 \\
\hline
\end{tabular}

Table 2 TTR-TR $\beta$ CALUX ${ }^{\odot} \mathrm{PC}_{80}, \mathrm{IC}_{50}$ values as well as thyroid hormone displacement activity (TTR-T4 $4_{\text {disp }}$ ) and lowest observed effect concentration (LOEC) of four self-synthesized single chain and four technical CP mixtures

\begin{tabular}{|c|c|c|c|c|c|c|}
\hline Sample & $\begin{array}{l}\text { Mean carbon formula } \\
{[\text { mean molar mass }(\mathrm{g} /} \\
\text { mol })]\end{array}$ & $\begin{array}{l}\text { Amount used in } \\
\text { stock solution (mg) }\end{array}$ & $\begin{array}{l}\mathrm{PC}_{80} \\
\text { (mmol/L } \\
\text { incubate) }\end{array}$ & $\begin{array}{l}\mathrm{IC}_{50}(\mathrm{mmol} / \mathrm{L} \\
\text { incubate })\end{array}$ & $\begin{array}{l}\text { TTR-T4 }{ }_{\text {disp }} \text { activ- } \\
\text { ity }(\mu \mathrm{g} \text { PFOA } \\
\text { equivalents/g) }\end{array}$ & $\begin{array}{l}\text { LOEC } \\
\text { (mmol/L } \\
\text { incubate) }\end{array}$ \\
\hline PFOA & $(414)$ & - & $8.15 \mathrm{E}-04$ & 0.00204 & - & \\
\hline $\mathrm{C}_{10}-\mathrm{CP}(49.3 . \% \mathrm{Cl})$ & $\mathrm{CH}_{1.82} \mathrm{Cl}_{0.38}(273)$ & 13.2 & 0.97 & $(-)$ & 1300 & 0.95 \\
\hline $\mathrm{C}_{11}-\mathrm{CP}(49.8 \% \mathrm{Cl})$ & $\mathrm{CH}_{1.77} \mathrm{Cl}_{0.41}$ (311) & 10.7 & 0.30 & 0.65 & 3600 & 0.30 \\
\hline $\mathrm{C}_{14}-\mathrm{CP}(50.1 \% \mathrm{Cl})$ & $\mathrm{CH}_{1.75} \mathrm{Cl}_{0.39}(384)$ & 12.3 & 0.053 & 0.21 & 9200 & 0.094 \\
\hline $\mathrm{C}_{16}-\mathrm{CP}(48.3 \% \mathrm{Cl})$ & $\mathrm{CH}_{1.74} \mathrm{Cl}_{0.36}(427)$ & 11.7 & 0.047 & 0.18 & 17,000 & 0.047 \\
\hline MCCP-1 $(53.1 \% \mathrm{Cl})$ & $\mathrm{CH}_{1.68} \mathrm{Cl}_{0.44}\left(440^{\mathrm{a}}\right)$ & 12.2 & 0.10 & $(-)^{\mathrm{b}}$ & 4200 & 0.18 \\
\hline MCCP-2 $(52.3 \% \mathrm{Cl})$ & $\mathrm{CH}_{1.68} \mathrm{Cl}_{0.44}\left(441^{\mathrm{a}}\right)$ & 12.9 & 0.36 & $(-)^{\mathrm{b}}$ & 2100 & 0.36 \\
\hline LCCP-1 $(41.1 \% \mathrm{Cl})$ & $\mathrm{CH}_{1.86} \mathrm{Cl}_{0.26}\left(578^{\mathrm{a}}\right)$ & 12.3 & 0.25 & $(-)^{\mathrm{b}}$ & 2300 & 0.24 \\
\hline LCCP-2 $(71.7 \% \mathrm{Cl})$ & $\mathrm{CH}_{1.20} \mathrm{Cl}_{0.93}\left(1150^{\mathrm{a}}\right)$ & 12.2 & 0.029 & $(-)^{\mathrm{b}}$ & 10,000 & 0.029 \\
\hline
\end{tabular}

${ }^{a}$ Exact chain length composition of the technical standards was unknown; therefore, the mean value of the contained chain lengths was chosen as an approximation: $\mathrm{C}_{15}$ for MCCPs $\left(\mathrm{C}_{14-17}\right)$ and $\mathrm{C}_{25}$ for LCCPs $\left(\mathrm{C}_{20-30}\right)$

${ }^{\mathrm{b}} \mathrm{IC}_{50}$ could not be determined because of biphasic behavior

CCC fractions giving response were removed and those of CPs without impurities were pooled (Table 1).

\section{TTR-TR $\beta$ CALUX ${ }^{\odot}$ assay of CP mixtures and perfluorooctanoic acid (PFOA)}

The TTR-TR $\beta$ CALUX bioassay was carried out by BioDetection Systems B.V. (BDS, Amsterdam, the Netherlands) under conditions described in detail previously (Collet et al. 2019). After dissolving 10-13 mg of CPs (Table 2) in $100 \mu \mathrm{L}$ of DMSO, serial dilutions of all samples were prepared in DMSO in log-scale increments of 0.5. Five (5) $\mu \mathrm{L}$ of diluted CP samples were mixed with $100 \mu \mathrm{L}$ TTR and $50 \mu \mathrm{L}$ T4 (final concentrations $0.058 \mu \mathrm{M}$ and $0.052 \mu \mathrm{M}$, respectively), both dissolved in Tris buffer ( $\mathrm{pH} \mathrm{8.0),} \mathrm{and}$ incubated in a final volume of $155 \mu \mathrm{L}$ overnight at $4{ }^{\circ} \mathrm{C}$. No precipitation of CPs was observed. TTR-bound T4 was separated from unbound (free) T4 by loading the total incubate on a pre-cooled Bio-Gel P-6DG column followed by $1 \mathrm{~min}$ centrifugation $(210 \mathrm{~g})$. One hundred and forty (140) $\mu \mathrm{L}$ of the collected eluate containing the TTR-bound T4 were mixed with $500 \mu \mathrm{L}$ serum-free assay medium and added to seeded and pre-incubated TR $\beta$ CALUX cells $(200 \mu \mathrm{L} /$ well; in triplicate; Table 3). After $24 \mathrm{~h}$ of exposure of the TR $\beta$ CALUX cells in a conditioned environment $\left(37^{\circ} \mathrm{C}, 5 \% \mathrm{CO}_{2}\right.$,
Table 3 CALUX ${ }^{\odot}$ cell culture and exposure medium information for the TR $\beta$ assay

\begin{tabular}{ll}
\hline Assay & TR $\beta$ \\
\hline Cell type & U2-OS \\
Species & Human \\
DMSO & $0.1 \%$ \\
Fold dilution & 1000 \\
$\mathrm{CO}_{2}$ & $5 \%$ \\
Exposure time & $24 \mathrm{~h}$ \\
Seeding concentration & 100,000 cells/mL (10,000 cells/well) \\
Medium used & DMEM/F-12 \\
Additions to medium & - Stripped fetal calf serum (cell culture only) \\
& - Non-essential amino acids \\
\hline
\end{tabular}

$100 \%$ humidity), the medium was removed and the cells were lysed with $30 \mu \mathrm{L}$ of a triton-lysis buffer. The induction of the luciferase production was quantified after addition of $100 \mu \mathrm{L}$ illuminate solution containing $15 \mu \mathrm{g}$ of the substrate D-luciferin and subsequent measurement of luminescence on a luminometer (Mithras LB949, Berthold Technologies, Bad Wildbach, Germany). As standard reference substance, a serial dilution series of PFOA (Sigma-Aldrich, Zwijndrecht, The Netherlands) in DMSO in log-scale increments of 0.5 was prepared $\left(4.6 \times 10^{-2}-1.3 \times 10^{-5} \mathrm{~mol} / \mathrm{L}\right)$ and $5 \mu \mathrm{L}$ 
of each dilution was incubated with $50 \mu \mathrm{L}$ T4 and $100 \mu \mathrm{L}$ TTR.

The thyroid hormone disruptive potential (activity) of tested substances was determined relative to the standard reference substance PFOA from the concentrations giving a decrease in TR $\beta$ activation of $20 \%\left(\mathrm{PC}_{80}\right)$. Results were interpolated in the calibration curve for quantitative determination of thyroid hormone transport disruptive potential using the statistical software package GraphPad Prism V5.03 (STATCON, Witzenhausen, Germany), and further statistical test were performed in IBM SPSS Statistics 26 (Armonk, NY, USA). Where appropriate, the 50\% maximal inhibitory concentration $\left(\mathrm{IC}_{50}\right.$ value) was calculated.

\section{Results}

CCC separation of the self-synthesized single chain length $\mathrm{CP}$ mixtures effectively removed all detectable amounts of sulfur-containing impurities from the raw products. The resulting, pure $\mathrm{CP}$ fractions showed smaller chlorination degrees than the raw mixtures (Table 1). Note, however, that the separated fractions were still dominated by CPs, and that the share of CPs in the raw product was much higher as may be concluded from the difference in sample weights before and after CCC as shown in Table 1. However, it was considered essential that any by-products were removed before the tests.

All eight CP samples showed activity in the TTR-TR $\beta$ CALUX $^{\Theta}$ (expressed as $\mu \mathrm{g}$ PFOA equivalent per g substance), indicating thyroid hormone transport disrupting potential (Table 2). The four single chain length CP mixtures showed similar chlorine contents $(48.3-50.1 \% \mathrm{Cl}$ content, section Industrial CP products and single chain length $\mathrm{CP}$ mixtures) and therefore similar mean carbon formulas (Sprengel and Vetter 2020). However, the TTR-T4 displacement $\left(\right.$ TTR-T $4_{\text {disp }}$ ) in the TTR-TR $\beta$-CALUX ${ }^{\odot}$ test increased in the order $\mathrm{C}_{10^{-}}<\mathrm{C}_{11^{-}}<\mathrm{C}_{14^{-}}<\mathrm{C}_{16^{-}}$CPs by more than one order of magnitude (from 1300 up to 17,000, Table 3). Hence, the response increased with the length of the alkyl chain, which indicated a higher activity of MCCPs in the test compared to SCCPs. All single chain CP mixtures showed a dose-response effect, with only $\mathrm{C}_{10}$-CPs not completely displacing T4 from TTR at the highest measured concentration (Fig. 1).

Also, the four industrial CP mixtures showed activity in the test. Two industrial MCCP mixtures from two producers showed similar $\% \mathrm{Cl}$ content and also the activity in the bioassay was in a similar range (Table 2). A high response was also observed for the two technical LCCP products. In this case, the activity of the highly chlorinated mixture $(71.7 \%$
TTR-TR $\beta$ CALUX
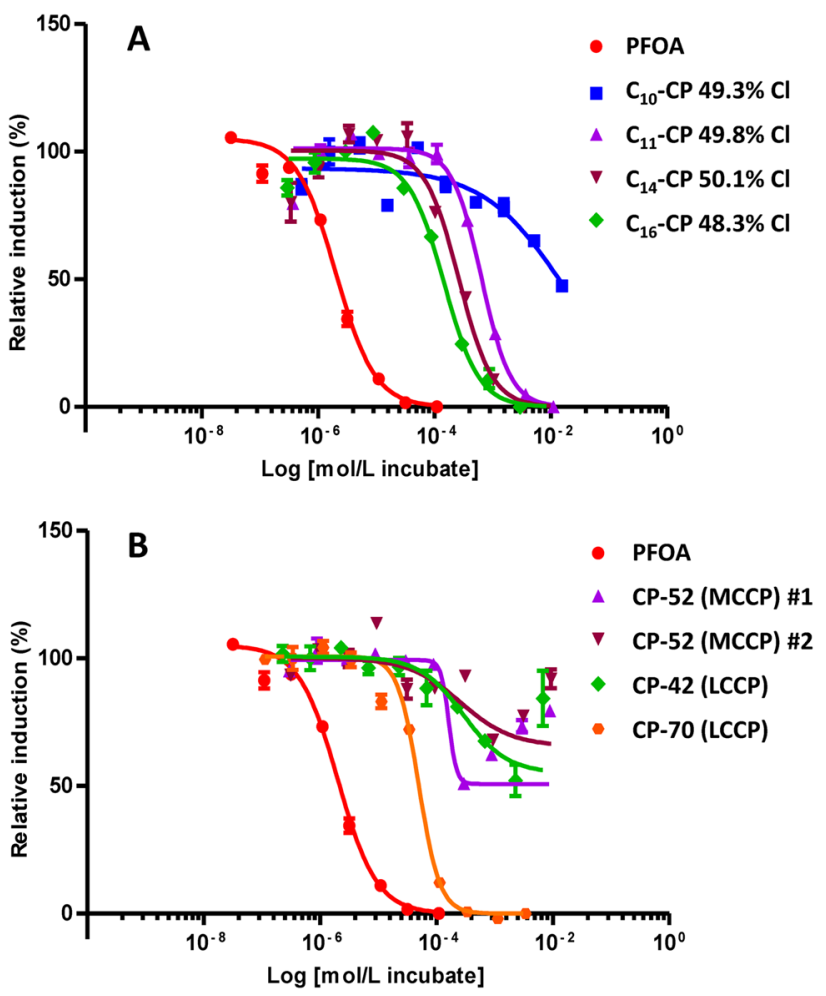

Fig. 1 Dose-response TTR-T4 displacement (TTR-T4 ${ }_{\text {disp }}$ ) curves of four self-synthesized single chain length CP standards (a) and four technical CP products (b) in the TTR-TR $\beta$ CALUX assay

$\mathrm{Cl}$ vs. $41.1 \% \mathrm{Cl}$ ) was more than fourfold higher (Table 3 ). Since the chain length composition of LCCPs could not be studied by GC/MS (chain lengths $>\mathrm{C}_{18}$ are difficult to analyze by GC (Schinkel et al. 2018)), it remained unclear if the dissimilarity in response was solely due to different degrees of chlorination or also affected by chain length composition. Irrespective of this uncertainty, the highly chlorinated industrial product LCCP-2 showed the second highest activity of the eight tested CP mixtures. Also, sample LCCP-2 showed the lowest observed effect level (LOEL) (Table 2) of all samples. In addition, LCCP-2 was the only industrial CP mixture that showed a dose-response effect like the single chain length CP mixtures (Fig. 1).

\section{Discussion}

Overall, the individual responses of the tested CPs varied by one order of magnitude and could not be traced back to specific properties of the samples. However, response of all tested CPs in the TTR-TR $\beta$ CALUX test indicated that all types of CPs (SCCPs, MCCPs and LCCPs) may possess 
thyroid disruptive potential. To our knowledge, this is the first report on possible toxic effects of LCCPs. Comparison of single chain CP mixtures of similar \% Cl (at $~ 48-50 \% \mathrm{Cl}$ ) indicated increasing activity and lower LOELs with increasing chain length (Table 3). The two industrial MCCP products were dominated by $\mathrm{C}_{14}$-congeners (share $>60 \%$ ). Still, the activity was lower than the one of the single chain $\mathrm{CP}$ mixtures. This indicated that other factors, e.g. specific but currently unknown structural units, could also play a role. However, neither chlorination degree or chain length nor CALUX activity or LOEL was found to be significantly correlated ( $p>>0.05$ for Pearson, Kendall-Tau and Spearmans Rho). Overall, limited information on the composition of CP mixtures prevented to determine the factors that were responsible for the different activities of the $\mathrm{CP}$ mixtures studied.

Irrespectively, reduced thyroid function as indicated in our tests can be harmful for the development of newborn babies (Spiliotis 2007). Recent studies described rising CP concentrations in mother's milk (Zhou et al. 2020; Liu et al. 2020), from which they can be transferred efficiently to the newborn (Liu et al. 2020). The observation of thyroid disruptive activity of CPs in the TTR-TR $\beta$-CALUX ${ }^{\odot}$ test may indicate a potential for thyroid hormone disruption when transferred from the mother to the infant. Hence, CP amounts in the diet of mothers should be as low as possible. Also, CPs were found to be present in commercial baby food (Krätschmer et al. 2021). Furthermore, additional thyroid toxicity tests featuring more different, but ideally, well-characterized CP mixtures are needed to clarify the factors that influence the different activity determined in the TTR-TR $\beta$-CALUX ${ }^{\odot}$ test.

Acknowledgments J. Sprengel would like to thank the Carl Zeiss Stiftung for granting his $\mathrm{PhD}$ project.

Funding Open Access funding enabled and organized by Projekt DEAL.

\section{Compliance with ethical standards}

Conflict of interest The authors declare that they have no conflict of interest.

Open Access This article is licensed under a Creative Commons Attribution 4.0 International License, which permits use, sharing, adaptation, distribution and reproduction in any medium or format, as long as you give appropriate credit to the original author(s) and the source, provide a link to the Creative Commons licence, and indicate if changes were made. The images or other third party material in this article are included in the article's Creative Commons licence, unless indicated otherwise in a credit line to the material. If material is not included in the article's Creative Commons licence and your intended use is not permitted by statutory regulation or exceeds the permitted use, you will need to obtain permission directly from the copyright holder. To view a copy of this licence, visit http://creativecommons.org/licenses/by/4.0/.

\section{References}

Conference of the Parties to the Stockholm Convention (2017) Decision SC-8/11: listing of short-chain chlorinated paraffins in Annex A, Geneva

Collet B, Simon E, van der Linden S, el Abdellaoui N, Naderman M, Man H, Middelhof I, van der Burg B, Besselink H, Brouwer A (2019) Evaluation of a panel of in vitro methods for assessing thyroid receptor $\beta$ and transthyretin transporter disrupting activities. Reprod Toxicol. https://doi.org/10.1016/j.reprotox.2019.05.011

Englert M, Hammann S, Vetter W (2015) Isolation of $\beta$-carotene, $\alpha$-carotene and lutein from carrots by countercurrent chromatography with the solvent system modifier benzotrifluoride. J Chromatogr A 1388:119-125. https://doi.org/10.1016/j.chrom a.2015.02.020

Friesen JB, McAlpine JB, Chen S-N, Pauli GF (2015) Countercurrent separation of natural products: an update. J Nat Prod 78(7):17651796. https://doi.org/10.1021/np501065h

Gallistl C, Vetter W (2016) Synthesis, liquid chromatographic fractionation and partial characterization of polybrominated dibenzofuran congeners. J Chromatogr A 1442:62-72. https://doi.org/10.1016/j. chroma.2016.03.015

Glüge J, Wang Z, Bogdal C, Scheringer M, Hungerbühler K (2016) Global production, use, and emission volumes of short-chain chlorinated paraffins - a minimum scenario. Sci Total Environ 573:1132-1146. https://doi.org/10.1016/j.scitotenv.2016.08.105

Glüge J, Schinkel L, Hungerbühler K, Cariou R, Bogdal C (2018) Environmental risks of medium-chain chlorinated paraffins (MCCPs): a review. Environ Sci Technol 52(12):6743-6760. https://doi. org/10.1021/acs.est.7b06459

Gong Y, Zhang H, Geng N, Xing L, Fan J, Luo Y, Song X, Ren X, Wang F, Chen J (2018) Short-chain chlorinated paraffins (SCCPs) induced thyroid disruption by enhancement of hepatic thyroid hormone influx and degradation in male Sprague Dawley rats. Sci Total Environ 625:657-666. https://doi.org/10.1016/j.scito tenv.2017.12.251

He C, Brandsma SH, Jiang H, O'Brien JW, van Mourik LM, Banks AP, Wang X, Thai PK, Mueller JF (2019) Chlorinated paraffins in indoor dust from Australia: levels, congener patterns and preliminary assessment of human exposure. Sci Total Environ 682:318323. https://doi.org/10.1016/j.scitotenv.2019.05.170

Heeb NV, Iten S, Schinkel L, Knobloch M, Sprengel J, Lienemann P, Bleiner D, Vetter W (2020) Characterization of synthetic singlechain CP standard materials-removal of interfering side products. Chemosphere 255:126959. https://doi.org/10.1016/j.chemo sphere.2020.126959

Hilger B, Fromme H, Völkel W, Coelhan M (2013) Occurrence of chlorinated paraffins in house dust samples from Bavaria, Germany. Environ Poll 175:16-21. https://doi.org/10.1016/j.envpo 1.2012.12.011

Ito Y (2005) Golden rules and pitfalls in selecting optimum conditions for high-speed counter-current chromatography. J Chromatogr A 1065(2):145-168. https://doi.org/10.1016/j.chroma.2004.12.044

Kapp T, Vetter W (2009) Offline coupling of high-speed counter-current chromatography and gas chromatography/mass spectrometry generates a two-dimensional plot of toxaphene components. J Chromatogr A 1216(47):8391-8397. https://doi.org/10.1016/j. chroma.2009.09.062

Krätschmer K, Schächtele A, Vetter W (2021) Chlorinated paraffins in baby food from the German market. Food Control. https://doi. org/10.1016/j.foodcont.2020.107689

Li T, Wan Y, Gao S, Wang B, Hu J (2017) High-throughput determination and characterization of short-, medium-, and longchain chlorinated paraffins in human blood. Environ Sci Technol 51(6):3346-3354. https://doi.org/10.1021/acs.est.6b05149 
Liu L, Li Y, Coelhan M, Chan HM, Ma W, Liu L (2016) Relative developmental toxicity of short-chain chlorinated paraffins in Zebrafish (Danio rerio) embryos. Environ Pollut 219:1122-1130. https://doi. org/10.1016/j.envpol.2016.09.016

Liu Y, Aamir M, Li M, Liu K, Hu Y, Liu N, Xu Y, Du J, Xu J, Liu W (2020) Prenatal and postnatal exposure risk assessment of chlorinated paraffins in mothers and neonates: occurrence, congener profile, and transfer behavior. J Hazard Mater 395:122660. https ://doi.org/10.1016/j.jhazmat.2020.122660

Schinkel L, Bogdal C, Canonica E, Cariou R, Bleiner D, McNeill K, Heeb NV (2018) Analysis of medium-chain and long-chain chlorinated paraffins: the urgent need for more specific analytical standards. Environ Sci Technol Lett 5(12):708-717. https://doi. org/10.1021/acs.estlett.8b00537

Spiliotis BE (2007) Thyroid function in the newborn and infant. In: Krassas GE, Rivkees SA, Kiess W (eds) Diseases of the thyroid in childhood and adolescence, 1 st edn. Karger, Freiburg, pp 44-55

Sprengel J, Vetter W (2019) Synthesis and characterization of eight single chain length chlorinated paraffin standards and their use for quantification. Rapid Commun Mass Spectrom 33(1):49-56. https://doi.org/10.1002/rcm.8310

Sprengel J, Vetter W (2020) NMR and GC/MS analysis of industrial chloroparaffin mixtures. Anal Bioanal Chem. https://doi. org/10.1007/s00216-020-02720-7

Sprengel J, Wiedmaier-Czerny N, Vetter W (2019) Characterization of single chain length chlorinated paraffin mixtures with nuclear magnetic resonance spectroscopy (NMR). Chemosphere 228:762768. https://doi.org/10.1016/j.chemosphere.2019.04.094

van Mourik LM, Gaus C, Leonards PEG, de Boer J (2016) Chlorinated paraffins in the environment: a review on their production, fate, levels and trends between 2010 and 2015. Chemosphere 155:415-428. https://doi.org/10.1016/j.chemosphere.2016.04.037
Vetter W, Kirres J, Bendig P (2012) Synthesis of polychlorinated terphenyl mixtures and gas chromatography with mass spectrometry data of tetra- to octachlorinated ortho-, meta-, and para-terphenyls. J Chromatogr A 1263:151-157. https://doi.org/10.1016/j. chroma.2012.09.032

Wang X-T, Jia H-H, Hu B-P, Cheng H-X, Zhou Y, Fu R (2019) Occurrence, sources, partitioning and ecological risk of short- and medium-chain chlorinated paraffins in river water and sediments in Shanghai. Sci Total Environ 653:475-484. https://doi. org/10.1016/j.scitotenv.2018.10.391

Weiss JM, Andersson PL, Lamoree MH, Leonards PEG, van Leeuwen SPJ, Hamers T (2009) Competitive binding of poly- and perfluorinated compounds to the thyroid hormone transport protein transthyretin. Toxicol Sci 109(2):206-216. https://doi.org/10.1093/ toxsci/kfp055

Wu J, Cao D, Gao W, Lv K, Liang Y, Fu J, Gao Y, Wang Y, Jiang G (2019) The atmospheric transport and pattern of Medium chain chlorinated paraffins at Shergyla mountain on the Tibetan Plateau of China. Environ Pollut 245:46-52. https://doi.org/10.1016/j. envpol.2018.10.112

Wyatt I, Coutss CT, Elcombe CR (1993) The effect of chlorinated paraffins on hepatic enzymes and thyroid hormones. Toxicology 77(1-2):81-90. https://doi.org/10.1016/0300-483X(93)90139-J

Zhou Y, Yuan B, Nyberg E, Yin G, Bignert A, Glynn A, Odland JØ, Qiu Y, Sun Y, Wu Y, Xiao Q, Yin D, Zhu Z, Zhao J, Bergman A (2020) Chlorinated paraffins in human milk from urban sites in China, Sweden, and Norway. Environ Sci Technol 54(7):43564366. https://doi.org/10.1021/acs.est.9b06089

Publisher's Note Springer Nature remains neutral with regard to jurisdictional claims in published maps and institutional affiliations. 